Gratsiana Florensiana Da Silva, Natalia R. Yulianti \& Apolonia A. Ina

Terapi Bermain Origami Untuk Menurunkan Kecemasan Anak Usia Prasekolah Selama Hospitalisasi

\title{
Terapi Bermain Origami Untuk Menurunkan Kecemasan Anak Usia Prasekolah Selama Hospitalisasi
}

\author{
Gratsiana Florensiana Da silva ${ }^{1}$, Natalia R. Yulianti ${ }^{2}$, Apolonia A. Ina ${ }^{3}$ \\ ${ }^{1)}$ Program Studi Sarjana Keperawatan STIKes St. Elisabeth Semarang \\ ${ }^{2), 3)}$ STIKes St. Elisabeth Semarang
}

Korespondensi penulis: natalia.r.yulianti@gmail.com

\begin{abstract}
Abstrak
Kecemasan merupakan salah satu distres psikologis ketika anak dirawat di rumah sakit. Terapi bermain dapat diberikan untuk mengatasi persoalan tersebut. Salah satu terapi bermain yang sesuai dengan pertumbuhan dan perkembangan anak usia pra sekolah adalah kegiatan origami. Penelitian membuktikan kegiatan origami dapat menurunkan tingkat kecemasaan anak usia pra sekolah yang mengalami hospitalisasi, namun masih diperlukan pembuktian selanjutnya dengan menambahkan jumlah sampel dan dengan uji statistik yang berbeda. Penelitian ini bertujuan menganalisis pengaruh terapi bermain origami untuk menurunkan kecemasan pada anak usia pra sekolah. Metode yang digunakan pada penelitian ini adalah kuasi eksperimental dengan rancangan one group pretes-post test yang dilakukan di dua rumah sakit daerah di Jawa Tengah. Sampel penelitian ini adalah pasien anak usia pra sekolah sebanyak 70 orang yang mengalami kecemasan dan baru pertama kali dirawat di rumah sakit. Teknik pengambilan sampel menggunakan consecutive sampling. Kecemasan anak diukur sebelum dan sesudah dilakukan terapi bermain origami menggunakan Preschool Anxiety Scale (PAS). Data dianalisis dengan menggunakan uji alternatif Wilcoxon dengan hasil p value <0,001. Disimpulkan bahwa terapi bermain origami dapat menurunkan kecemasan anak usia pra sekolah yang mengalami hospitalisasi. Perawat dapat menerapkan terapi bermain origami pada anak usia pra sekolah yang mengalami kecemasan saat dirawat di rumah sakit dengan melibatkan orang tua. Penelitian selanjutnya dapat mengukur keefektifan terapi bermain origami untuk menurunkan kecemasan dengan kelompok kontrol dan dengan jumlah sampel yang lebih banyak.
\end{abstract}

Kata kunci: anak usia pra sekolah; terapi bermain; hospitalisasi; kecemasan; origami

\section{PENDAHULUAN}

Hospitalisasi didefinisikan oleh Merriam-Webster Dictionary sebagai suatu tindakan/proses perawatan di rumah sakit atau suatu keadaan seseorang dirawat di rumah sakit (Merriam-Webster, 2015). Sementara itu, anak melihat hospitalisasi sebagai suatu usaha untuk kembali menjadi sehat secara utuh dan mendapatkan kembali status individu di dunia (Bsiri-Moghaddam, BasiriMoghaddam, Sadeghmoghaddam, \& Ahmadi, 2011).
Namun demikian, kecemasan anak ketika dirawat di rumah sakit tidak dapat dihindarkan dan ini menjadi salah satu distres psikologis selama dirawat di rumah sakit. Salah satu kecemasan tersebut adalah kecemasan karena perpisahan atau disebut separation anxiety karena mereka berpisah dari keluarga dan teman-teman mereka. Kelompok usia anak yang mengalami separation anxiety ini adalah anak prasekolah (Potts \& Mandleco, 2012; Hockenberry \& Wilson, 2015). Bentuk 
Gratsiana Florensiana Da Silva, Natalia R. Yulianti \& Apolonia A. Ina

Terapi Bermain Origami Untuk Menurunkan Kecemasan Anak Usia Prasekolah Selama Hospitalisasi

kecemasan pada anak usia pra sekolah seperti menolak makan, mengalami sulit tidur, terus bertanya kapan orang mereka akan datang, atau menarik diri dari orang lain (Hockenberry \& Wilson, 2015)

Untuk mengatasi kecemasan anak tersebut, anak dapat diikutkan dalam terapi bermain. Sebuah literatur review yang dilakukan oleh Koukourikos, Tzeha, Pantelidou, \& Tsaloglidou (2015) menyimpulkan bahwa bermain dapat mengurangi emosi negatif pada anak yang sedang dirawat di rumah sakit. Sementara itu, penelitian selanjutnya yang dilakukan di Tamil Naidu mendukung literatur review tersebut dengan membuktikan bahwa bermain memiliki pengaruh yang signifikan untuk mengurangi kecemasan anak (Davidson, Satchi, \& Venkatesan, 2017). Bermain juga dapat dilakukan sebagai persiapan perawatan. Sebelum masuk di ruang perawatan, anak diajak bermain di ruang admisi. Kegiatan ini terbukti efektif menurunkan kecemasan pada anak di Hamadan, Iran (Sadeghian, Seif, Aahmadi nia, \& Khalili, 2019).

Kegiatan bermain memiliki berbagai variasi. Salah satu kegiatan bermain yang sesuai dengan perkembangan anak usia pra sekolah adalah kegiatan melipat kertas atau yang biasa disebut sebagai origami. Sebuah literatur review menyebutkan bahwa origami telah menjadi kegiatan keterampilan bagi $97 \%$ anak pra sekolah di Jepang dan praktik ini telah dilakukan lebih dari 140 tahun (Nishida, 2019). Origami menjadi pilihan kegiatan bagi anak pra sekolah karena pada usia ini, anak berada pada tahap perkembangan bermain sosial dan fantasi. Kegiatan origami dapat memenuhi tugas perkembangan fantasi pada anak (Jones, 2018). Selanjutnya, fantasi anak dapat mendukung kreativitas anak. Penelitian(Setiawati, 2019) pada siswa PAUD di Cimahi Tengah membuktikan bahwa origami mampu meningkatkan kemampuan berkreasi anak. Selain itu, origami juga mampu meningkatkan kemampuan motorik halus anak usia pra sekolah, seperti yang telah dibuktikan oleh Widayati, Simatupang, \& Sari (2019) pada penelitiannya pada anak PAUD di Indonesia.

Oleh karenanya origami menjadi pilihan kegiatan bermain untuk anak usia pra sekolah yang dirawat di rumah sakit untuk mengurangi kecemasan mereka dan penelitian membuktikan origami dapat menurunkan kecemasan anak usia pra sekolah ketika menjalani perawatan di rumah sakit (Mathew \& H, 2018; Alihsan, Santi, \& Setyowati, 2018; Juwita, 2019; Kodiriya, Munir, Kholisotin, Fauzi, \& Wahid, 2019).

Di suatu rumah sakit umum daerah di Jawa Tengah terdapat 228 anak usia pra sekolah yang dirawat dalam tiga bulan terakhir. Sebagai dampak perawatan tersebut, anak-anak rentan mengalami kecemasan. Kegiatan bermain origami yang terbukti efektif menurunkan kecemasan dapat diterapkan di rumah sakit ini. Namun, diperlukan pengujian kembali untuk keefektifan tersebut dengan menambahkan sampel (Mathew \& H, 2018). Selanjutnya, Kodiriya et al. (2019) telah melakukan menambahkan sampel namun dengan pengukuran kecemasan yang berbeda dengan menggunakan HARS dan analisis ANOVA test. Oleh karena itu, diperlukan pengujian kembali dengan menambahkan jumlah sampel dan menggunakan uji statistik yang berbeda dari yang telah dilakukan 
Gratsiana Florensiana Da Silva, Natalia R. Yulianti \& Apolonia A. Ina

Terapi Bermain Origami Untuk Menurunkan Kecemasan Anak Usia Prasekolah Selama Hospitalisasi

sebelumnya. Penelitian ini bertujuan untuk mengukur keefektifan kegiatan bermain origami terhadap penurunan kecemasan anak usia pra sekolah yang mengalami hospitalisasi dengan jumlah sampel yang lebih banyak dan dengan uji statistik yang berbeda.

\section{METODE}

Penelitian ini merupakan jenis penelitian Quasi Experiment dengan rancangan one group pretest-postest. Hipotesis penelitian ini adalah $\mathrm{H} 1$ : Ada pengaruh terapi bermain origami terhadap kecemasan anak usia prasekolah yang mengalami hospitalisasi. H0: Tidak ada pengaruh terapi bermain origami terhadap kecemasan anak usia prasekolah yang mengalami hospitalisasi.

Penelitian ini dilakukan di dua rumah sakit daerah di Jawa Tengah yang dilaksanakan pada bulan Juli 2019. Teknik pengambilan sampel dalam penelitian ini adalah teknik consecutive sampling dengan responden 70 sampel. Pemilihan sampel dilakukan berdasarkan kriteria inklusi: 1) Anak usia prasekolah yang baru pertama kali dirawat di rumah sakit dan yang mengalami kecemasan; 2) Anak usia prasekolah yang tidak memiliki kondisi penyakit gawat dan sakit kritis; 3) Anak usia prasekolah yang didampingi orang tua atau keluarga, pendamping; dan kriteria ekslusi: 1) Anak tidak kooperatif; 2) Anak tidak dalam pengobatan anti cemas; 3) Anak memiliki gangguan pertumbuhan dan perkembangan seperti autis, ADHD atau retardasi mental.

Data yang telah terkumpul diuji normalitas dengan aplikasi SPSS yang menggunakan rumus Kolmogorov-Smirnov karena sampel $>50$. Hasil uji normalitas sebelum dan sesudah dilakukan terapi bermain origami didapatkan nilai $\rho$ value $0,001(<0,05)$ dan 0,002 $(<0,05)$ maka disimpulkan data tidak terdistribusi normal sehingga dilakukan transformasi data menggunakan log 10. Hasil transformasi sebelum dan sesudah dilakukan terapi bermain origami didapatkan nilai $\mathrm{p}$ value 0,001 dan 0,001 maka disimpulkan distribusi data tidak normal. Selanjutnya data diuji dengan uji alternatif Wilcoxon menggunakan data awal.

\section{HASIL}

1. Analisa Univariat

a. Karakteristik Responden

Berdasar-kan Jenis Kelamin

Tabel 3. Distribusi Frekuensi Jenis Kelamin Responden $(n=70)$

\begin{tabular}{ccc}
\hline $\begin{array}{c}\text { Jenis } \\
\text { Kelamin }\end{array}$ & Frekuensi & Persen \\
\hline Laki - laki & 27 & 38.6 \\
Perempuan & 43 & 61.4 \\
Total & 70 & 100.0 \\
\hline
\end{tabular}

Tabel diatas menunjukkan bahwa responden anak berjenis kelamin perempuan berjumlah 43 anak $(61,4 \%)$ dan laki-laki berjumlah $27(38,6 \%)$. b. Karakteristik Responden
Berdasarkan Usia

Tabel 4. Distribusi Frekuensi 
Gratsiana Florensiana Da Silva, Natalia R. Yulianti \& Apolonia A. Ina Terapi Bermain Origami Untuk Menurunkan Kecemasan Anak Usia Prasekolah Selama Hospitalisasi

Usia Responden $(\mathrm{n}=70)$

\begin{tabular}{ccc}
\hline Usia & Frekuensi & Persen \\
\hline 3 & 22 & 31.4 \\
4 & 23 & 32.9 \\
5 & 15 & 21.4 \\
6 & 10 & 14.3 \\
Total & 70 & 100.0 \\
\hline
\end{tabular}

Tabel diatas menunjukkan bahwa responden anak yang berusia 3 tahun berjumlah 22 anak $(31,4 \%)$ berusia 4 tahun berjumlah $23 \quad \operatorname{anak}(32,9 \%)$ berusia 5 tahun berjumlah 15 anak $(21,4 \%)$ berusia 6 tahun berjumlah $10(14,3 \%)$.

\section{c.Distribusi Frekuensi \\ Kecemasan Sebelum \\ Dilakukan Terapi Bermain \\ Origami}

Tabel 5. Distribusi frekuensi kecemasan sebelum dilakukan terapi bermain origami $(n=70)$

Kecemasan Frekuensi Persen

$\begin{array}{lll}\text { Tidak cemas } & 0 & 0 \\ \text { Kecemasan ringan } & 6 & 8.6\end{array}$

Kecemasan sedang $\quad 25 \quad 35.7$

Kecemasan berat $\quad 39 \quad 55.7$

$\begin{array}{lll}\text { Total } & 70 & 100.0\end{array}$

Tabel diatas menunjukkan bahwa responden anak yang mengalami kecemasan ringan berjumlah 6 anak $(8,6 \%)$, kecemasan sedang berjumlah 25 $(35,7 \%)$, dan kecemasan berat berjumlah $39(55,7 \%)$.

c. Distribusi Frekuensi Kecemasan Setelah Dilakukan Terapi Bermain Origami

Tabel 6. Distribusi frekuensi kecemasan setelah dilakukan terapi bermain origami $(n=70)$

\begin{tabular}{lcc}
\hline \multicolumn{1}{c}{ Kecemasan } & Frekuensi & Persen \\
\hline Tidak cemas & 16 & 22.9 \\
Kecemasan ringan & 44 & 62.9 \\
Kecemasan sedang & 10 & 14.3 \\
Kecemasan berat & 0 & 0 \\
Total & 70 & 100.0 \\
\hline
\end{tabular}

Tabel diatas menunjukkan bahwa responden anak yang tidak cemas berjumlah 16 anak $(22,9 \%)$, kecemasan ringan berjumlah 44 anak (62,9\%), kecemasan sedang berjumlah 10 anak $(14,3 \%)$.

\section{Analisa Bivariat}

Tabel 7. Perbedaan sebelum dan sesudah dilakukan terapi bermain origami terhadap anak usia prasekolah yang mengalami hospitalisasi bulan Juli $2019(n=70)$

\begin{tabular}{lccr}
\hline & $\mathrm{n}$ & $\begin{array}{c}\text { Median } \\
(\text { Min-Max) }\end{array}$ & $\mathrm{P}$ \\
\hline $\begin{array}{l}\text { Kecemasan } \\
\text { (pre) }\end{array}$ & 70 & $\begin{array}{c}46.00 \\
(16-52)\end{array}$ & \\
$\begin{array}{l}\text { Kecemasan } \\
\text { (post) }\end{array}$ & 70 & $\begin{array}{c}20.00 \\
(8-34)\end{array}$ & \\
\hline
\end{tabular}

Berdasarkan tabel di atas dapat diketahui bahwa hasil uji alternatif Wilcoxon sebelum dan sesudah dilakukan terapi bermain origami menunjukkan nilai signifikansi $p$ value < 0,001 . Berdasarkan hasil uji Wilcoxon tersebut dapat disimpulkan bahwa $\mathrm{H}_{0}$ ditolak dan $\mathrm{H}_{1}$ diterima, yang artinya ada pengaruh terapi bermain origami terhadap kecemasan anak usia prasekolah yang mengalami hospitalisasi. 
Gratsiana Florensiana Da Silva, Natalia R. Yulianti \& Apolonia A. Ina

Terapi Bermain Origami Untuk Menurunkan Kecemasan Anak Usia Prasekolah Selama Hospitalisasi

Penelitian ini membuktikan bahwa terapi bermain origami dapat menurunkan kecemasan anak pra sekolah yang mengalami hospitalisasi. Dengan demikian penelitian ini memperkuat hasil penelitian-penelitian sebelumnya (Mathew \& H, 2018; Alihsan, Santi, \& Setyowati, 2018; Kodiriya, Munir, Kholisotin, Fauzi, \& Wahid, 2019; \& Juwita, 2019). Terapi bermain origami mampu menurunkan kecemasan anak ketika dirawat di rumah sakit karena kegiatan bermain dapat mengurangi stres dan membebaskan anak dari tekanan. Hal tersebut disebabkan anak-anak diberi kebebabasn mengkespresikan ketakutan, kekuatiran, dan kecemasan mereka. Kegiatan origami memberikan kesempatan anak membuat bentuk-bentuk yang ada di sekitar rumah sakit. Sambil melipat kertas, anak dapat mengekspresikan perasaan mereka tentang benda-benda atau lingkungan fisik yang ada di rumah sakit. Bermain juga menjadi sumber pengalihan yang mengurangi separation anxiety. Ketika anak fokus bermain origami, anak akan sudah tidak mengingat lagi saudara, orang tua, atau teman mereka. Lebih lanjut ketika anak bermain, mereka merasa aman karena mereka yakin bahwa mereka tidak akan mendapatkann prosedur yang menyakitkan. Ketika anak bermain origami, mereka merasa senang sehingga mereka merasa bahwa berada di rumah sakit adalah sama menyengangkannya ketika berada di rumah atau sekolah. Dengan demikian kecemasan anak dapat berkurang (Wilkins, 2014).

Keberhasilan tersebut
mengabaikan faktor yang
mempengaruhi kecemasan anak
seperti pengalaman perawatan di
rumah sakit sebelumnya. Anak yang

sebelumnya pernah dirawat di rumah sakit akan lebih mudah beradaptasi dengan perpisahan dan kondisi di rumah sakit (Hockenberry \& Wilson, 2015). Penelitian ini menunjukkan bahwa walaupun anak baru pertama kali dirawat di rumah sakit, semuanya mengalami penurunan kecemasan setelah dilakukan terapi bermain origami.

Namun demikian tingkat kecemasan anak pada penelitian ini beragam dari kecemasan ringan, sedang, sampai dengan berat. Hal ini dapat disebabkan karena setiap anak memiliki cara masing-masing dalam menghadapi keadaan yang tidak menyenangkan seperti dirawat di rumah sakit. Perbedaan itu dipengaruhi oleh kekuatan yang ada dalam diri anak yang salah satunya adalah kemampuan koping anak, seperti kemampuan mengekspresikan ketakutan mereka, mencari informasi tentang apa yang terjadi sampai akhirnya mereka menguasai keadaan tersebut. Selain itu, talenta masingmasing anak dapat membantu anak menghadapi stresor selama perawatan di rumah sakit, misalnya anak yang pintar menggambar dapat mengekspresikan perasaan mereka melalui media gambar (Potts \& Mandleco, 2012).

Perkembangan strategi koping anak telah dirangkum dalam suatu literatur review yang menyebutkan bahwa koping anak usia prasekolah adalah dengan cara distraksi (ZimmerGembeck \& Skinner, 2011). Penelitian ini membuktikan bahwa terapi bermain origami mampu menurunkan kecemasan anak prasekolah selama hospitalisasi sehingga dapat menjadi referensi bagi perawat dalam mendistraksi anak ketika mengalami kecemasan selama hospitalisasi. 
Gratsiana Florensiana Da Silva, Natalia R. Yulianti \& Apolonia A. Ina

Terapi Bermain Origami Untuk Menurunkan Kecemasan Anak Usia Prasekolah Selama Hospitalisasi

Selanjutnya perawat dapat mengajarkan orang tua tentang teknik distraksi ini karena salah satu bentuk partisipasi orang tua dalam perawatan anak adalah mendapatkan pendidikan kesehatan dan terlibat dalam proses perawatan anak mereka selama di rumah sakit. Kegiatan ini disebut sebagai hubungan mutualisme antara perawat dan orang tua anak (Potts \& Mandleco, 2012 \& Vasli \& Salsali, 2014).

\section{KESIMPULAN}

Penelitian ini kembali membuktikan bahwa terapi bermain origami mampu menurunkan kecemasan anak usia prasekolah selama hospitalisasi. Oleh karenanya perawat dapat menggunakan terapi ini dengan melibatkan orang tua selama perawatan anak di rumah sakit. Penelitian selanjutnya dapat mengukur keefektifan terapi bermain origami dengan menambahkan kelompok kontrol dengan jumlah sampel yang lebih banyak.

\section{DAFTAR PUSTAKA}

Al-ihsan, M., Santi, E., \& Setyowati, A. (2018). Terapi Bermain Origami Terhadap Kecemasan Anak Usia Prasekolah. Dunia Keperawatan, 6, 63-70. https://doi.org/10.20527/dk.v6i1. 5086

Bsiri-Moghaddam, K., BasiriMoghaddam, M., Sadeghmoghaddam, L., \& Ahmadi, F. (2011). The concept of hospitalization of children from the view point of parents and children. Iranian Journal of Pediatrics, 21(2), 201-208.

Davidson, B., Satchi, N. S., \& Venkatesan, D. L. (2017). Effectiveness of play therapy upon anxiety among hospitalised children. International Journal of Advance Research, Ideas and Innovations in Technology, 3(5), 441-444. Retrieved from https://www.ijariit.com/manuscri pts/v3i5/V3I5-1295.pdf

Hockenberry, M. J., \& Wilson, D. (2015). Wong's nursing care of infants and children (10th ed.). Missouri: Elsevier Inc.

Jones, M. (2018). The necessity of play for children in health care. Pediatric Nursing, 44(6), 303$305 . \quad$ Retrieved from http://search.ebscohost.com/login .aspx ?direct $=$ true $\& \mathrm{db}=\mathrm{ehh} \& \mathrm{AN}=$ $133645947 \&$ site $=$ ehost-live

Juwita, H. (2019). Effectiveness of Multimodal Interventions Play Therapy: Colouring and Origami Against Anxiety Levels in Toddler Ages. Journal of Health Science and Prevention, 3(3S), 46-51.

https://doi.org/10.29080/jhsp.v3i3 s. 288

Kodiriya, N. S., Munir, Z., Kholisotin, K., Fauzi, A. K., \& Wahid, A. H. (2019). The effectiveness of playing Clay and Origami therapy to reduce anxiety pediatric patients hospitalized. Jurnal Aisyah: Jurnal Ilmu Kesehatan, 4(2), 151-160. https://doi.org/10.30604/jika.v4i2 .200

Koukourikos, K., Tzeha, L., Pantelidou, P., \& Tsaloglidou, A. (2015). The importance of play during hospitalization of children. Materia Socio Medica, 27(6), 438.

https://doi.org/10.5455/msm.2015 $.27 .438-441$

Mathew, C. S., \& H, D. C. (2018). Effectiveness of origami on 
Gratsiana Florensiana Da Silva, Natalia R. Yulianti \& Apolonia A. Ina

Terapi Bermain Origami Untuk Menurunkan Kecemasan Anak Usia Prasekolah Selama Hospitalisasi

hospitalized anxiety among children. International Journal of Advance Research and Development, 3(8), 169-173.

Merriam-Webster. (2015). Merriam Webster Dictionary. Retrieved April 24, 2020, from MerriamWebster Inc. website: http://www.merriamwebster.com/dictionary/quality

Nishida, Y. (2019). Something old, something new, something borrowed, and something froebel? The development of origami in early childhood education in Japan. Paedagogica Historica, 55(4), 529-547. https://doi.org/10.1080/00309230 .2018 .1546330

Potts, N. L., \& Mandleco, B. L. (2012). Pediatric nursing, caring for children and their families. In Usa.

Sadeghian, E., Seif, M., Aahmadi nia, H., \& Khalili, A. (2019). The effect of preparation for hospitalization on cchool-Age children's anxiety during admission at Hamadan Besat Educational Hospital. Avicenna Journal of Nursing and Midwifery Care, 27(3), 149-155. https://doi.org/10.30699/ajnmc.27 .3 .149

Setiawati, W. (2019). Increasing creativity of early childhood through origami playing activities. Jurnal Empowerment, 8(1), 81-89. https://doi.org/10.22460/empowe rment.v8i1p81-89.1163

Vasli, P., \& Salsali, M. (2014). Parents' participation in taking care of hospitalized children: a concept analysis with hybrid model. Iranian Journal of Nursing and Midwifery Research,
19(2), 139-144. Retrieved from http://www.ncbi.nlm.nih.gov/pub med/24834082\%0Ahttp://www.p ubmedcentral.nih.gov/articlerend er.fcgi?artid=PMC4020022

Widayati, S., Simatupang, N. D., \& Sari, P. P. (2019). The Impact of Adduction of Folding Paper Stages for Children's Fine Motor Skills. Advance in Social Science, Education and Humanities Research, 387(Icei), 62-65. https://doi.org/10.2991/icei19.2019.14

Wilkins, L. W. \&. (2014). Pediatric Nursing Made Incredibly Easy. In M. Meadows-Oliver (Ed.), Wolters Kluwer Health (Second, Vol. 29). https://doi.org/10.1097/00152193 -199905000-00020

Zimmer-Gembeck, M. J., \& Skinner, E. A. (2011). The development of coping across childhood and adolescence: An integrative review and critique of research. International Journal of Behavioral Development, 35(1), 1-17. https://doi.org/10.1177/01650254 10384923 